\title{
Effects of timber harvest on phlebotomine sand flies (Diptera: Psychodidae) in a production forest: abundance of species on tree trunks and prevalence of trypanosomatids
}

\author{
Felipe Arley Costa Pessoa/ ${ }^{+}$, Jansen Fernandes Medeiros*, Toby Vincent Barrett**
}

\begin{abstract}
Laboratório de Biodiversidade, Centro de Pesquisa Leônidas e Maria Deane, Fiocruz-Amazônia, Rua Teresina 476, 69057-070
Manaus, AM, Brasil *Coordenação de Pesquisas em Ciências da Saúde **Coordenação de Pesquisas em Entomologia, Instituto Nacional de Pesquisas da Amazônia, Manaus, AM, Brasil
\end{abstract}

The Amazon forest is being exploited for timber production. The harvest removes trees, used by sand flies as resting sites, and decreases the canopy, used as refuges by some hosts. The present study evaluated the impact of the timber harvest, the abundance of sand flies, and their trypanosomatid infection rates before and after selective logging. The study was accomplished in terra-firme production forest in an area of timber harvest, state of Amazonas, Brazil. Sand fly catches were carried out in three areas: one before and after the timber harvest, and two control areas, a nature preservation area and a previously exploited area. The flies were caught by aspiration on tree trunks. Samples of sand flies were dissected for parasitological examination. In the site that suffered a harvest, a larger number of individuals was caught before the selective extraction of timber, showing significant difference in relation to the number of individuals and their flagellate infection rates after the logging. The other two areas did not show differences among their sand fly populations. This fact is suggestive of a fauna sensitive to the environmental alterations associated with selective logging.

Key words: environmental impacts - Phlebotominae - Trypanosomatidae - Central Amazon

Phlebotomine sand flies (Diptera: Psychodidae) are insects of medical and veterinary importance, as they can transmit leishmaniasis, bartonellosis, and arboviruses. In Amazonia, these insects have a high richness of species (Young \& Duncan 1994) and high indices of local diversity in terra-firme forest (Barrett et al. 1996). In spite of this, the ecological studies on Amazonian species of phlebotomine sand flies are still scarce and almost restricted to the Leishmania (Kinetoplastida: Trypanosomatidae) vectors. This fact may be explained in part because of the diurnal resting places of a considerable part of the forest phlebotomine species are unknown. Among the few species of phlebotomine that can be easily found in the forest, are those that rest in the base of tree-trunks. Systematic collections on trunk trees, relating species of trees, and phlebotomine sand flies were done by Geoffroy et al. (1985) in the French Guyana and by Cabanillas and Castellón (1999) in Brazilian Central Amazonia. Although the predominant species in both papers was Lutzomyia umbratilis Ward \& Frahia, some differences occurred in the faunistic composition of the other species of sand flies, showing a different characterization of specific fauna for each region.

In Costa Rica, Memmott (1991) found that 97\% of the phlebotomines caught on tree trunks were composed of four species. To the author (Memmott 1991, 1992), the bases of trees are mating and resting places, swarming place, and source of vertebrate hosts.

Financial support: Inpa, PPI 1-3060

${ }^{+}$Corresponding author: facpessoa@amazonia.fiocruz.br

FACP was financed by $\mathrm{CNPq}$

Received 25 January 2007

Accepted 11 June 2007
Amazonia has been exploited intensively in relation to timber. The harvest removes a substrate (bases of trees) used as resting places by sand flies and opens up the canopy used by vertebrate hosts. The females of phlebotomines need to engorge on vertebrate blood to develop their eggs, so alterations in the macrofauna may have reflections in the fauna of those insects. The adults of sand flies need vegetable sugars (Cameron et al. 1995) and the larvae are dentrivores or feed on small organisms in the soil (Hanson 1968), and probably will be affected by the changes of edaphic fauna and microclimatic alterations (Rutledge \& Ellenwood 1975).

Although the direct contact between man and phlebotomine foci on the bases of trees is an important source for human infection, the variation of the infection rates of females in time and space has not been systematically studied. The effects of timber harvest on the infection rates of females of those species are unknown. According to Walsh et al. (1993) deforestation results in inevitable effects on vector-borne disease, which in tropical rain forests have rarely been adequately documented. Each environmental change by natural phenomena or through human intervention alters the ecological balance and context within which vectors and their parasites breed develop and transmit diseases (Patz et al. 2000). The present study evaluated the effect of the timber harvest on the abundance of sand flies and their flagellate infection rates. This study is probably the first to evaluate the logging effects on tree-inhabiting sand fly fauna in Amazonia.

\section{MATERIALS AND METHODS}

The Mil Madeireira production forest is an area of $806 \mathrm{~km}^{2}$ and mainly of terra-firme vegetation under sustained management located north of the Amazon River 
in the municipalities of Silves and Itacoatiara, in the state of Amazonas between $2^{\circ} 43^{\prime} \mathrm{S}$ and $3^{\circ} 04^{\prime} \mathrm{S}$ and $58^{\circ} 31^{\prime} \mathrm{W}$ and $58^{\circ} 57^{\prime} \mathrm{W}$. The management plan is based on compartments of 2000 ha, one or more of which is selectively logged annually.

The study was realized in three different areas: (a) Compartment $\mathrm{N}$, area with timber harvest during the study where the sand flies collections were accomplished before and after the timber harvest, (b) a preservation area (PA), as control area, and (c) a second control area, Compartment A, where previous exploitation had been made. In Compartment $\mathrm{N}$, the selected trees were those not destined to the harvest of 1999. Ten trees were selected in each study area, and all of them identified by the keys of Ribeiro et al. (1999). The selection of the trees was based on previous collections to verify the constancy of sand fly populations on the base of these trees. Only trees with a good number of sand flies were chosen.

The trees had similar size, with height over $20 \mathrm{~m}$ and girth $>50 \mathrm{~cm}$ (Table I). During the catches, three people worked simultaneously in each area, during the morning, in the interval between 9:00-11:00 AM, when sand flies are known to be present on the trunk of trees, near the roots (Arias \& Freitas 1982). Samples were obtained by sweeping the tree base, using a CDC trap attached to a conventional gauze insect cage as aspirator (KillickKendrick 1987), during at least 10 min per tree. The cage was replaced after the collection from each tree. Six systematic collections were made, between July and November of 1999, a dry period, when the Mil Madeireira company usually starts the timber exploitation. The capture effort in collecting sand flies was three days per collection. The N Compartment was logged at the end of September of 1999. The three areas were sampled simultaneously for three days for each of three collections before and three collections after the harvest in compartment $\mathrm{N}$.

Portions of the female sand flies from each sample were dissected individually in a drop of sterile saline solution on a microscope slide and the digestive tract examined with a phase contrast microscope to detect the presence of flagellates. Identification and classification of the sand flies follows Young and Duncan (1994).

The Kruskall-Wallis test was used to compare the population of sand flies and the trypanosomatid rates among the studied areas. In order to compare the effects of the timber harvest on the sand fly phlebotomine populations and their trypanosomatid infection rates, we used the Mann-Whitney Rank Sum test (Zar 1974).

TABLE I

List of selected trees for the systematic collections of phlebotomine sand flies in the $\mathrm{N}$ and A compartments and preservation area, Madeireira Mil, Itacoatiara, AM, Brazil

\begin{tabular}{|c|c|c|c|}
\hline Areas & No. & Tree species & Family \\
\hline \multirow[t]{10}{*}{ Compartment $\mathrm{N}$} & 1 & Sloanea sp.1 & Elaenocarpaceae \\
\hline & 2 & Caryocar pallidum A.C.Sm. & Caryocaraceae \\
\hline & 3 & Eschweirela micrantha (Berg) Myers & Lecythidaceae \\
\hline & 4 & Lecythis prancei S.A.Mori & Lecythidaceae \\
\hline & 5 & Lycania sp. & Chrysobalanaceae \\
\hline & 6 & Micropholis sp. & Sapotaceae \\
\hline & 7 & Cryssophyllum amazonicum T.D.Penn. & Sapotacea \\
\hline & 8 & Caryocar pallidum A.C.Sm. & Caryocaraceae \\
\hline & 9 & Crysophyllum manaosense T.D.Penn. & Sapotaceae \\
\hline & 10 & Caryocar pallidum A.C.Sm. & Caryocaraceae \\
\hline \multirow[t]{10}{*}{ Preservation area } & 1 & Licania sp. & Chrysobalanaceae \\
\hline & 2 & Iryanthera lancifolia Ducke & Myristicaceae \\
\hline & 3 & Cariniana micrantha Ducke & Lecythidaceae \\
\hline & 4 & Eschweirela micrantha (Berg) Myers & Lecythidaceae \\
\hline & 5 & Iryanthera lancifolia Ducke & Myristaceae \\
\hline & 6 & Eschweirela pseudodecolorans S.A.Mori & Lecythidaceae \\
\hline & 7 & Licania sp. & Chrysobalanaceae \\
\hline & 8 & Licania impressa Prance & Chrysobalanaceae \\
\hline & 9 & Not identified & Lauraceae \\
\hline & 10 & Caryocar pallidum A.C.Sm. & Caryocaraceae \\
\hline \multirow[t]{10}{*}{ Compartment A } & 1 & Pouteria flavilatex T.D.Penn. & Sapotaceae \\
\hline & 2 & Eschweirela coriacea (DC.) Mart. ex Berg & Lecythidaceae \\
\hline & 3 & Eschweirela micrantha (Berg) Miers & Lecythidaceae \\
\hline & 4 & Scleronema micrantha Ducke & Bombacaceae \\
\hline & 5 & Sextonia rubra (Mez) van der Werff & Lauraceae \\
\hline & 6 & Goupia glabra Ducke & Goupiaceae \\
\hline & 7 & Glycydendron amazonicum Ducke & Euphorbiaceae \\
\hline & 8 & Eschweirela coriacea (DC.) Mart. ex Berg & Lecythidaceae \\
\hline & 9 & Sclerobium melanocarpum Ducke & Leguminosae \\
\hline & 10 & Vatairea paraensis (DC.) Mart. ex Berg & Leguminosae \\
\hline
\end{tabular}

Slonaea sp.1: probably an undescribed species. 


\section{RESULTS}

Distribution of phlebotomine and flagellate infections by sampling plot and tree species - On the 30 chosen trees, 5222 phlebotomine sand flies were collected, representing 11 species of the genus Lutzomyia. L. (Nyssomyia) umbratilis was the predominant species with $78.14 \%$ of the collected specimens, followed by three species of the subgenus Psathyromyia, with $18.47 \%$ of the specimens (Table II).

Significantly more sand flies were collected in N Compartment with 2763 specimens $(\mathrm{H}=9508$, $\mathrm{p}=$ 0.009; Kruskal-Wallis) than in PA, with 1512 flies or A Compartment, with 947 specimens (Table III).

In $\mathrm{N}$ Compartment, the trees with higher numbers of collected sand flies were (by individual tree) Caryocar pallidum and Eschweirela micrantha, and the trees with less sand flies were Sloanea sp. 1 and Lecythis prancei (Table III). In PA, the trees with the highest number of collected sand flies were: Cariniana micrantha and Iryanthera lancifolia; and the trees with the smallest number of sand flies were E. micrantha e I. lancifolia (Table III). In A Compartment, the trees with the higher number of sand flies collected were E. micrantha and Pouteria flavilatex, and the trees with less sand flies were Goupia glabra and Glycydendron amazonicum (Table III). The sand fly species with higher relative frequencies in the three areas were L. umbratilis, followed by L. dendrophyla and L. shannoni (Table II).

A total of 562 females of sand flies (27.04\%) of eight species were dissected. Overall, flagellates were found in 64 (13.8\%) of L. umbratilis, 17 (35.4\%) of L. shannoni, and $4(15.1 \%)$ of L. rorotaensis (Table VI). The N Compartment had more infected phlebotomine sand flies $(\mathrm{H}=$ 14.42; $\mathrm{p}<0.001$ ) than A Compartment and PA (Table VI). Trypanosomatid infection rates in flies collected in different tree species in the three plots are shown in Table IV.

Populations of phlebotomine sand flies before and after the timber harvest - In N Compartment more sand flies were collected in July to September (pre-harvest) than in October to November (post-harvest) $(\mathrm{T}=66 ; \mathrm{p}=$
0.047 Mann-Whitney) (Table V). In the control plots A Compartment and PA, there were no significant differences between samples collected in the two periods ( $\mathrm{T}$ $=74, \mathrm{p}=0.170, \mathrm{~T}=81, \mathrm{p}=0.365$, respectively).

Infection rates of trypanosomatids in phlebotomine sand flies, before and after the timber harvest - In the $\mathrm{N}$ Compartment 61 infected females were found before the timber harvest and only 14 after the harvest $(U=64$, $\mathrm{p}=0.031$; Mann-Whitney) (Table VI). The rates of infected phlebotomine sand flies collected in A Compartment and PA were not significantly different before and after the harvest in $\mathrm{N}$ Compartment $(\mathrm{U}=70, \mathrm{p}=0.095$ and $U=75, p=0.193$; Mann-Whitney, respectively).

\section{DISCUSSION}

Almost 60 species within 29 families of trees have been indicated as a resting place of phlebotomine sand flies: Central Amazonia of Brazil, Itacoatiara municipality, Amazonas (present study) and Adolpho Ducke Forest Reserve in Manaus municipality, Amazonas (Cabanillas \& Castellón 1999); Panama (Rutledge \& Mosser 1971, Chaniotis et al. 1972,1974, Rutledge \& Elenwood 1975, Christensen \& Vasquez 1983, Memmott 1991); French Guiana (Geofroy et al 1985); and Peru (Parrot 1935).

Those species of trees showed some common characteristics and the most outstanding is that all the tree species concerned reach the canopy of the forest. Ready et al. (1986) analyzed some characteristics in 120 trees (simple trunk with buttresses, bark furrowed or scaly smooth, foliage in part of upper canopy or under storey only) in the state of Pará, Brazil and they observed that L. umbratilis had a preference for large trees whose branches interlock in the upper canopy. In the present study, relative abundances in sand fly species (Table III) were similar to those observed elsewhere (Barrett et al. 1991, Geoffroy et al. 1985, Cabanillas \& Castellón 1999); where L. umbratilis, followed by some species of the subgenus Psathyromyia and L. rorotaensis were the predominant species on tree trunks. The low frequencies of the other species registered on tree bases in

\section{TABLE II}

Phlebotomine sand fly species caught on the base of trees in the $\mathrm{N}$ and A compartments and the preservation area, Mil Madeireira, Itacoatiara, AM, Brazil, during July 7 to November 25, 1999

\begin{tabular}{|c|c|c|c|c|}
\hline Species & Male & Female & Total & $\%$ \\
\hline Lutzomyia (Nyssomyia) umbratilis Ward \& Frahia & 2415 & 1663 & 4078 & 78.14 \\
\hline L. (Psathyromyia) dendrophyla (Mangabeira) & 396 & 135 & 531 & 10.17 \\
\hline L. (Psathyromyia) shannoni (Dyar) & 146 & 139 & 285 & 5.45 \\
\hline L. (Psathyromyia) scaffi (Damasceno \& Arouk) & 80 & 16 & 96 & 1.83 \\
\hline L. (Psathyromyia) abonnenci (Floch \& Chassignet) & 27 & 13 & 40 & 0.76 \\
\hline L. (Psathyromyia) lutziana (Costa Lima) & 9 & 5 & 14 & 0.26 \\
\hline L. (Psychodopygus) davisi (Root) & 0 & 2 & 2 & 0.04 \\
\hline L.(Lutzomyia) spathotrichia Martins, Falcão \& Silva & 30 & 18 & 48 & 0.91 \\
\hline L. rorotaensis (Group Oswaldoi) (Floch \& Abbonnenc) & 26 & 64 & 90 & 1.72 \\
\hline L. (Pintomyia) christenseni Young \& Duncan & 6 & 19 & 25 & 0.48 \\
\hline L. (Viannamyia) furcata (Mangabeira) & 9 & 4 & 13 & 0.24 \\
\hline Total & 3144 & 2078 & 5222 & 100 \\
\hline
\end{tabular}


TABLE III

Relative frequencies of phlebotomine sand flies on the selected species of trees of $\mathrm{N}$ and A compartments and preservation area (PA), Mil Madeireira, Itacoatiara, AM, Brazil, during July 7 to November 25, 1999

\begin{tabular}{|c|c|c|c|c|c|c|c|c|}
\hline \multirow[b]{2}{*}{ Tree species } & \multicolumn{8}{|c|}{ Species } \\
\hline & 1 & 2 & 3 & 4 & 5 & 6 & $\%$ & Total \\
\hline \multicolumn{9}{|l|}{ N Compartment } \\
\hline Sloanea sp. & 67,5 & 18,0 & 8,2 & 2,7 & 0,0 & 3,6 & 100 & 111 \\
\hline Caryocar pallidum & 85,5 & 8,6 & 3,4 & 0,5 & 0,2 & 1,8 & 100 & 407 \\
\hline Eschweirela micrantha & 93,0 & 2,2 & 3,0 & 0,6 & 0,6 & 0,6 & 100 & 276 \\
\hline Lecythis prancei & 75,2 & 15,9 & 6,3 & 0,0 & 0,0 & 2,6 & 100 & 113 \\
\hline Lycania sp. & 69,0 & 8,6 & 9,9 & 9,9 & 0,0 & 2,6 & 100 & 152 \\
\hline Micropholis sp. & 68,5 & 12,6 & 8,3 & 2,6 & 1,1 & 6,9 & 100 & 300 \\
\hline Cryssophyllum amazonicum & 66,7 & 23,0 & 6,3 & 2,0 & 0,5 & 1,5 & 100 & 192 \\
\hline Caryocar pallidum & 83,4 & 9,4 & 5,7 & 0,4 & 0,1 & 1,0 & 100 & 599 \\
\hline Crysophyllum manaosense & 79,5 & 11,9 & 7,8 & 0,0 & 0,0 & 0,8 & 100 & 244 \\
\hline Caryocar pallidum & 84,5 & 8,2 & 5,1 & 1,7 & 0,5 & 0,0 & 100 & 369 \\
\hline Total & & & & & & & & 2763 \\
\hline \multicolumn{9}{|l|}{ PA } \\
\hline Licania sp. & 83,0 & 4,9 & 4,1 & 1,8 & 0,0 & 6,2 & 100 & 272 \\
\hline Iryanthera lancifolia & 77,9 & 12,2 & 6,9 & 0,8 & 2,2 & 0,0 & 100 & 231 \\
\hline Cariniana micrantha & 87,0 & 5,0 & 2,5 & 1,7 & 0,5 & 3,3 & 100 & 362 \\
\hline Eschweirela micrantha & 78,9 & 0,0 & 0,0 & 1,7 & 1,7 & 10,7 & 100 & 57 \\
\hline Iryanthera lancifolia & 75,0 & 7,3 & 10,3 & 4,4 & 1,5 & 1,5 & 100 & 69 \\
\hline Eschweirela pseudodecolorans & 82,9 & 15,8 & 1,3 & 0,0 & 0,0 & 0,0 & 100 & 77 \\
\hline Licania $\mathrm{sp}$ & 77,7 & 15,0 & 0,8 & 0,8 & 0,8 & 4,9 & 100 & 122 \\
\hline Licania impressa & 71,5 & 12,2 & 13,1 & 1,6 & 1,6 & 0,8 & 100 & 123 \\
\hline Tree 9 & 90,6 & 2,0 & 3,4 & 0,0 & 0,0 & 3,0 & 100 & 101 \\
\hline Caryocar pallidum & 81,5 & 5,1 & 8,3 & 0,0 & 0,0 & 5,1 & 100 & 98 \\
\hline Total & & & & & & & & 1512 \\
\hline \multicolumn{9}{|l|}{ A Compartment } \\
\hline Pouteria flavilatex & 87,0 & 2,6 & 5,2 & 2,6 & 0,5 & 2,1 & 100 & 195 \\
\hline Eschweirela coriacea & 92,2 & 5,7 & 1,5 & 0,0 & 0,0 & 0,6 & 100 & 207 \\
\hline Eschweirela micrantha & 89,0 & 0,0 & 2,5 & 0,8 & 1,8 & 5,9 & 100 & 120 \\
\hline Scleronema micrantha & 49,3 & 25,4 & 11,9 & 0,0 & 1,5 & 11,9 & 100 & 69 \\
\hline Sextonia rubra & 41,3 & 30,7 & 0,0 & 0,0 & 0,0 & 28,0 & 100 & 77 \\
\hline Goupia glabra & 43,8 & 12,5 & 0,0 & 0,0 & 0,0 & 43,7 & 100 & 16 \\
\hline Glycydendron amazonicum & 82,6 & 6,9 & 0,0 & 0,0 & 0,0 & 10,5 & 100 & 29 \\
\hline Eschweirela coriacea & 76,2 & 17,9 & 0,0 & 4,7 & 0,0 & 1,2 & 100 & 84 \\
\hline Lerobium melanocarpum & 69,4 & 9,7 & 0,0 & 18,0 & 0,0 & 2,9 & 100 & 72 \\
\hline Vatairea paraensis & 75,6 & 1,3 & 3,8 & 0,0 & 3,8 & 15,5 & 100 & 78 \\
\hline Total & & & & & & & & 947 \\
\hline
\end{tabular}

1: Lutzomyia umbratilis; 2: L. dendrophyla; 3: L. shannoni, 4: L. scaffi; 5: L. abonnenci; 6: other species of sand flies (L. rorotaensis; L. spathotrichia; L. christenseni; L. lutziana; L. davisi; L. furcata); Tree 9: tree not identified, family Lauraceae.

Itacoatiara may indicate that they use the trunks only as occasional resting sites or reflect low natural abundance.

The relative frequencies of collected sand flies were constants in the three studied areas, reinforcing the hypothesis of an intrinsic relationship between the sand fly fauna and the microenvironment of tree bases. These results suggest that there is not an obligate direct relation between the sand fly population and particular tree species. The nature of attraction of some species of phlebotomine sand flies to certain trees is not explained yet. Memmott $(1991,1992)$ did not find any significant difference in the turnover rate of Lutzomyia sand flies on trees with naturally abundant sand flies compared to trees on which sand flies had been experimentally transplanted. This indicated that the trees without flies were suitable for using as a resting site, but were apparently lacking in some other attribute important to the flies. She proposed that for sand fly aggregation, microenvironment of tree bases, the presence of vertebrate hosts, and branches interlocking in the upper canopy could be of importance. Rutledge and Ellenwood (1975) suggested that shading and rain exposure of the trunk and the amount of litter influence aggregation.

Flagellate infections - The high rates of trypanosomatids in dissected sand flies in this work were expected. Some previous work developed in Amazonas and Pará, Brazil, with similar sand fly fauna and leishmaniasis foci, demonstrated infection rates comparable to those reported here (Arias \& Freitas 1978, Arias et al. 1985, Lainson et al. 1979, 1981, Freitas et al. 2002). In N Compartment and PA, the trees where we found more infected individuals were not those with the greatest num- 
TABLE IV

Natural infection by Trypanosomatidae in sand flies on tree species at the N Compartment (CN), preservation area (PA), and A Compartment (CA), Mil Madeireira, Itacoatiara, AM, during July 7 to November 25, 1999

\begin{tabular}{|c|c|c|c|c|c|c|c|c|}
\hline \multirow[b]{2}{*}{ Tree species } & \multicolumn{2}{|c|}{$\mathrm{CN}$} & \multicolumn{2}{|c|}{ PA } & \multicolumn{2}{|c|}{$\mathrm{CA}$} & \multicolumn{2}{|c|}{ Total } \\
\hline & NI & $\%$ & NI & $\%$ & NI & $\%$ & NI & $\%$ \\
\hline Sloanea sp. & 5 & 7.7 & 4 & 26.7 & - & - & 9 & 10.6 \\
\hline Caryocar pallidum & 25 & 38.5 & 0 & 0.0 & - & - & 25 & 29.4 \\
\hline Eschweirela micrantha & 22 & 33.8 & 1 & 6.7 & 0 & 0 & 23 & 27.0 \\
\hline Eschweirela pseudodecolorans & - & - & 0 & 0.0 & - & - & 0 & 0.0 \\
\hline Eschweirela coriacea & - & - & - & - & 2 & 40 & 2 & 2.3 \\
\hline Lecythis prancei & 4 & 6.2 & - & - & - & - & 4 & 4.7 \\
\hline Licania impressa & - & - & 2 & 13.3 & - & & 2 & 2.4 \\
\hline Lycania sp. & 0 & 0.0 & 5 & 33.3 & - & - & 5 & 5.9 \\
\hline Cryssophyllum amazonicum & 4 & 6.2 & - & - & - & - & 4 & 4.7 \\
\hline Crysophyllum manaosense & 3 & 4.6 & - & - & - & & 3 & 3.5 \\
\hline Micropholis $s p$. & 2 & 3.0 & - & - & - & - & 2 & 2.3 \\
\hline Pouteria flavilatex & - & - & - & - & 3 & 60 & 3 & 3.5 \\
\hline Iryanthera lancifolia & - & - & 2 & 13.3 & - & - & 2 & 2.3 \\
\hline Cariniana micrantha & - & - & 1 & 6.7 & - & - & 1 & 1.2 \\
\hline Total & 65 & 100 & 15 & 100 & 5 & 100 & 85 & 100 \\
\hline
\end{tabular}

TABLE V

Descriptive analysis of populations of sand flies collected per day in the A and N Compartment and the preservation area, Mil Madeireira, Itacoatiara, AM, during July 7 to November 25, 1999

\begin{tabular}{llrr}
\hline Area & Period & Mean & Total \\
\hline N Compartment & July-September $^{a}$ & $218,55 \pm 172,00(16-577)$ & 1967 \\
& October-November & & \\
Preservation area & July-September & $99,44 \pm 99,74(6-272)$ & 695 \\
& October-November & $71,22 \pm 75,01(5-201)$ & 841 \\
A Compartment & July-September & $96,77 \pm 97,23(27-321)$ & 671 \\
& October-November & $69,67 \pm 127,82(0-400)$ & 319 \\
\hline
\end{tabular}

$a:$ there are significant differences.

TABLE VI

Relative frequency of Trypanosomatidae infection in sand flies pre-harvest of trees (during July and September) at the N Compartment post-harvest (during October and November), and respective trypanosomatid frequencies in the A Compartment and the preservation area (PA) control groups, Mil Madeireira, Itacoatiara, AM, Brazil

\begin{tabular}{|c|c|c|c|c|c|c|c|c|c|c|c|c|}
\hline \multirow[b]{3}{*}{ Sand fly species } & \multicolumn{12}{|c|}{ Before selective timber logging } \\
\hline & \multicolumn{3}{|c|}{ A Compartment } & \multicolumn{3}{|c|}{ N Compartment } & \multicolumn{3}{|c|}{ PA } & \multicolumn{3}{|c|}{ Total } \\
\hline & DF & IF & $\%$ & $\mathrm{DF}$ & IF & $\%$ & DF & $\mathrm{IF}$ & $\%$ & $\mathrm{DF}$ & IF & $\%$ \\
\hline L. umbratilis & 38 & 3 & 7.9 & 172 & 41 & 23.8 & 42 & 3 & 7.1 & 252 & 47 & 18.7 \\
\hline L. shannoni & 2 & 0 & 0 & 13 & 8 & 61.5 & 4 & 3 & 75.0 & 19 & 12 & 63.2 \\
\hline L. rorotaensis & 7 & 2 & 28.6 & 2 & 2 & 100.0 & 0 & 0 & 0.0 & 9 & 4 & 44.5 \\
\hline \multirow[t]{2}{*}{ Total } & 47 & 5 & 10.4 & 187 & 61 & 32.6 & 46 & 6 & 13 & 280 & 63 & 22.5 \\
\hline & & \multicolumn{11}{|c|}{ After selective timber logging } \\
\hline L. umbratilis & 28 & 1 & 3.6 & 77 & 9 & 11.7 & 117 & 7 & 5.1 & 222 & 17 & 7.65 \\
\hline L. shannoni & 1 & 0 & 0.0 & 19 & 5 & 26.3 & 9 & 1 & 11.1 & 29 & 6 & 20.7 \\
\hline L. rorotaensis & 1 & 0 & 0.0 & 7 & 0 & 0.0 & 1 & 0 & 0.0 & 9 & 0 & 0 \\
\hline Total & 30 & 1 & 3.3 & 103 & 14 & 13.6 & 127 & 7 & 5.5 & 260 & 23 & 8.85 \\
\hline
\end{tabular}

DF: dissected females; IF: infected females. 
ber of sand flies (Tables III, IV). In Mil Madeireira, the most abundant populations of sand flies probably contained a higher proportion of younger females not yet exposed to vertebrate reservoirs of trypanosomatids (cf. Ready et al. 1986)

Impact of the timber harvest on sand fly populations - In N Compartment, the sand fly populations suffered a significant decrease after the selective timber harvest realized in October 1999. In the other areas (A Compartment and PA) the number of sand flies collected remained relatively constant. Although the logging impact in N Compartment negatively affected sand fly abundance, medically important species were still able to exploit the modified environment. Travi et al. (2002) working in a tropical dry forest in Northern Colombia, came to a similar conclusions, comparing sand fly abundance and diversity of a natural forest reserve with a highly degraded area.

There are few studies on the impact of changes in the vegetation on arthropods, especially medically important insects. Travi et al. (2002) compared the abundance of phlebotomine sand flies in Colombia, in degraded and preserved dry forests. Wilson et al. (2002) demonstrated replacement of forest species by savannah complex species, as effects of deforestation on black fly populations, using cytological probes for African black flies. Studies using other insects as biodiversity indicators in Amazonia have been tested, especially with butterflies and ants. Moutinho (1998) and Carvalho and Vasconcelos (1999) showed a reduction on the number of collected species of ants, between natural forest areas and degraded areas, in northern Pará and Central Amazonia. In Manaus, Brazil, Brown (1991) found an increase of Lepidoptera species in secondary forests, compared with primary forests. Similar comparison has been made with scarabaeid beetles in primary forest, near Manaus, that suffered fragmentation, showing a decrease in the abundance and diversity of these insects (Klein 1989). In studies of environment impacts in Marabá, Pará, Oliveira et al. (1999), showed a drastic difference in the ground invertebrate macrofauna, between a primary and a secondary forest. The results of our work suggest tree-inhabiting sand flies are sensitive to selective logging of even moderate intensity.

Rates of natural infection of trypanosomatids in phlebotomine sand flies, before and after the selective timber harvest - The rate of females infected by trypanosomatids in N Compartment, suffered a significant decrease after the selective timber harvest. The other areas (A Compartment and PA) did not show difference between sand fly infection rates as shown in the period of sand fly collection in the N Compartment area. The decrease of infected sand flies in N Compartment after the harvest had a direct relation with the decrease of sand fly population of that area. The timber harvest may have caused immediate high mortality or migration to areas near the impacted area with better conditions of life for these insects. The subsequent renovation of early emerged nuliparous flies may explain the lower infection rates after the harvest. As an alternative hypothesis, the harvest may cause an impact on the mammalian hosts fauna such as the two-toed sloth, causing their migration to areas less impacted and thus directly influencing the sand flies and their infection rates.

Although the logging impact in N Compartment had negatively affected sand fly abundance and the rates of infected females, the populations of $L$. umbratilis and other species were still capable of maintaining the life cycle of local trypanosomatids.

\section{ACKNOWLEDGEMENTS}

To the Late Dr Raul Guerra de Queiroz, adviser of the first author. To Dr Mike Hopkins (Sapeca), by the plant identification. The Mil Madeireira directors by help facilities.

\section{REFERENCES}

Arias JR, Freitas RA 1978. Sobre os vetores de leishmaniose cutânea na Amazônia Central do Brasil. 2: Incidência de flagelados em flebotomíneos selváticos. Acta Amazonica 8: 387-396.

Arias JR, Freitas RA 1982. On the vectors of cutaneous leishmaniasis in the Central Amazon of Brazil. 3. Phlebotomine sand fly stratification in a terra firme forest. Acta Amazonica 12: 599-608.

Arias JR, Miles MA, Naiff RD, Povoa MM, Freitas RA, Biancardi CB, Castellon EG 1985. Flagellate infections of Brazilian sandflies (Diptera: Psychodidae): Isolation in vitro and biochemical identification of Endotrypanum and Leishmania. Am J Trop Med Hyg 34: 1098-1108.

Barrett TV, Freitas RA, Albuquerque MIC, Hurtado Guerrero JC 1996. Report on a collection of Lutzomyia sand flies (Diptera: Psychodidae) from the Middle Solimões (Amazonas, Brazil). Mem Inst Oswaldo Cruz 91: 27-35.

Barrett TV, Freitas RA, Naiff MF, Naiff RD 1991. As leishmânias e seus transmissores em relação à saúde na Amazônia. In AL Val, R Figliuolo, E Feldberg, Bases Científicas para Estratégias de Preservação e Desenvolvimento da Amazônia: Fatos e Perspectivas, Vol. 1, Inpa, Manaus, p. 105117.

Brown KS 1991. Conservation of Neotropical environments: insects as indicators. In The Conservation of Insects and their Habits, 15th Symposium of the Royal Entomological Society of London, Academic Press, New York, p. 350-404.

Cabanillas MRS, Castellón EG 1999. Distribution of sandflies (Diptera: Psychodidae) on tree-trunks in a non-flooded area of the Ducke Forest Reserve, Manaus, AM, Brazil. Mem Inst Oswaldo Cruz 94: 289-296.

Cameron MM, Pessoa FAC, Vasconcelos AW, Ward RD 1995. Sugar meals sources for the phlebotomine sandfly Lutzomyia longipalpis, in Ceará State, Brazil. J Med Entomol 9: 263-272.

Carvalho KS, Vasconcelos HL 1999. Forest fragmentation in Central Amazonia and its effects on litter-dwelling ants. Biol Consev 91: 151-157.

Chaniotis BN, Tesh RB, Correa MA, Johnson KM 1972. Diurnal resting sites of phlebotomine sandflies in a Panamanian tropical forest. J Med Entomol 9: 91-98.

Chaniotis BN, Tesh RB, Correa MA, Johnson KM 1974. Horizontal and vertical movements of phlebotomine sandflies in a Panamanian rain forest. J Med Entomol 11: 369-375. 
Christensen HA, Vasquez AM 1983. The tree-buttress biotope: a pathobiocenose of Leishmania braziliensis. Am J Trop Med Hyg 31: 243-251.

Freitas RA, Naiff RD, Barrett TV 2002. Species diversity and flagellate infections in the sand fly fauna near Porto Grande, state of Amapá, Brazil (Diptera: Psychodidae. Kinetoplastida: Trypanosomatidae). Mem Inst Oswaldo Cruz 97: 53-59.

Geoffroy B, Dedet JP, Lebbe J, Esterre P, Trappe JF 1985. Notes sur les relation des veucteurs de leishmaniose avec les essence forestiéres en Guyane Française. Ann Parasitol Hum Cотр 61: 483-490.

Hanson WS 1968. The Immature Stages of the Subfamily Phlebotomine in Panama (Diptera: Psychodidae), $\mathrm{PhD}$ Thesis, University of Kansas, Kansas, 206 pp.

Klein BC 1989. Effects of forest fragmentation on dung and carrion beetle communities in Central Amazonia. Ecology 70: $1715-1725$.

Killick-Kendrick R 1987. Appendix II. Methods for the study of phlebotomine sandflies. In W Peters, R Killick-Kendrick, The Leishmaniases in Biology and Medicine, Vol. 1, Academic Press, London, p. 473-497.

Lainson R, Shaw JJ, Ward RD, Ready PD, Naiff RD 1979. Leishmaniasis in Brazil: XIII. Isolations of Leishmania from armadillos (Dasypus novemcinctus), and observations on the epidemiology of cutaneous leishmaniasis in north Para State. Trans R Soc Trop Med Hyg 73: 239-242.

Lainson R, Shaw JJ, Ready PD, Miles MA, Póvoa M 1981. Leishmaniasis in Brazil: XVI. Isolation and identification of Leishmania species from sandflies, wild mammals and man in north Pará State, with particular reference to Leishmania braziliensis guyanensis causative agent of "pian bois". Trans $R$ Soc Trop Med Hyg 75: 530-536.

Memmott J 1991. Sandfly distribution and abundance in a tropical rain forest. J Med Entomol 5: 403-411.

Memmott J 1992. Patterns of sandfly distribution in tropical forest: A causal hypothesis. Med Vet Entomol 6: 188-194.

Moutinho PRS 1998. Impactos da formação de pastagens sobre a fauna de formigas: conseqüências para a recuperação florestal na Amazônia oriental. In C Gascon, P Moutinho, Floresta Amazônica: Dinâmica, Regeneração e Manejo, Inpa, Manaus, p. 155-170.

Oliveira EP, Mitja D, Barbosa E, Luizão F, Miranda I, Ferraz I, Topall O, Desjardin T 1999. Impactos ambientais das atividades agrosilviopastoris sobre ecossistemas amazônicos e opções de sustentabilidade. In Anais do Seminário de
Integração dos Projetos de Pesquisa Dirigida, Subprograma de C \& T/PPDG-7, Programa Piloto para Proteção das Florestas Tropicais do Brasil. Manaus, AM, Brasil, 6-9 dezembro, p. 191-204.

Parrot L 1935. Phlebotomes et végétation. Bull Soc Path Exot 1: 960-963.

Patz JA, Graczyk TK, Geller N, Vittor AY 2000. Effects of environmental change on emerging parasitic diseases. Int $J$ Parasitol 30: 1395-1405.

Ready PD, Lainson R, Ward RD 1986. The ecology of Lutzomyia umbratilis Ward \& Frahia (Diptera: Psychodidae), the major vector to man of Leishmania braziliensis guyanensis in northeastern Amazonian Brazil. Bull Entomol Res 76: 21-40.

Ribeiro JELS, Hopkins MJG, Vincentini A, Sothers CA, Costa MAS, Brito JM, Souza MA, Martins LH, Lohmann LG, Assunção PACL, Pereira EC, Silva CF, Mesquita MR, Procópio LC 1999. Guia de Identificação das Plantas Vasculares de uma Floresta de Terra-firme na Amazônia Central, Inpa, Manaus, 816 pp.

Rutledge LC, Ellenwood DA 1975. Production of phlebotomine sandflies on the open forest floor in Panama: phytologic and edaphic relations. Environ Entomol 4: 83-89.

Rutledge LC, Mosser HL 1971. Biology of immature sandflies (Diptera: Psychodidae) at the base of trees in Panama. Environ Entomol 1: 300-309.

Travi BL, Adler GH, Lozano M, Cadena H, Motntoya-Lerma J 2002. Impact of habitat degradation on Phlebotominae (Diptera: Psychodidae) of tropical dry forests in Northern Colombia. J Med Entomol 39: 451-456.

Walsh JF, Molyneux DH, Birley MH 1993. Deforestation: effects on vector-borne disease. Parasitology 106: 55-75.

Wilson MD, Cheke RA, Flasse PJ, Grist S, Osei-Ateweneboana MY, Tetteh-Kumah A, Fiasorgbor GK, Jolliffe FR, Boakye DA, Hougard JM, Yameogo L, Post R 2002. Deforestation and the spatio-temporal distribution of savannah and forest members of the Simulium damnosum complex in southern Ghana and south-western Togo. Trans R Soc Trop Med Hyg 96: 632-639.

Young DG, Duncan MA 1994. Guide to identification and geographic distribution of Lutzomyia sand flies in Mexico, the West Indies, Central and South America (Diptera: Psychodidae) $M$ Amer Entomol Inst 54: 1-881.

Zar JH 1974. Biostatistical Analysis, Englewood Cliffs, PrenticeHall, London, 512 pp. 
